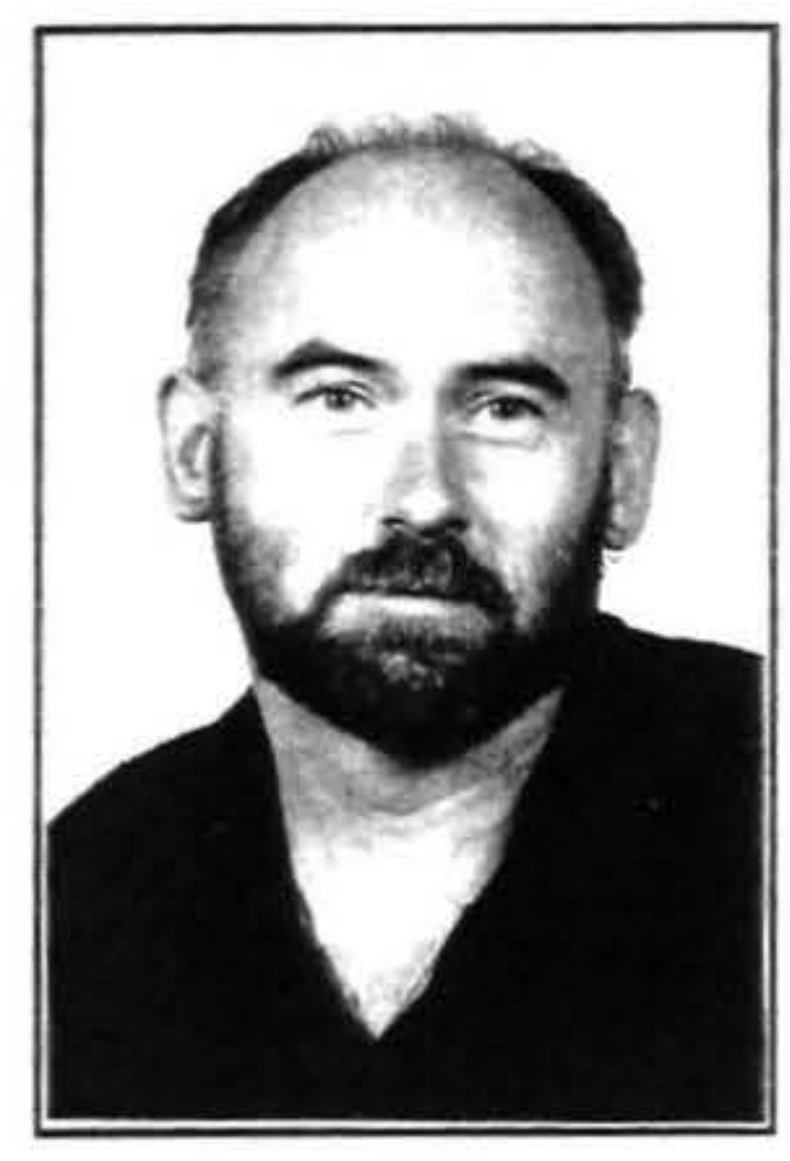

\title{
OCCUPATIONAL AND INDUSTRY FORECASTS OF EMPLOYMENT: IMPLICATIONS FOR MAORI
}

\author{
Grant Andrews and Dennis Rose \\ Business and Economic Research Ltd (BERL)
}

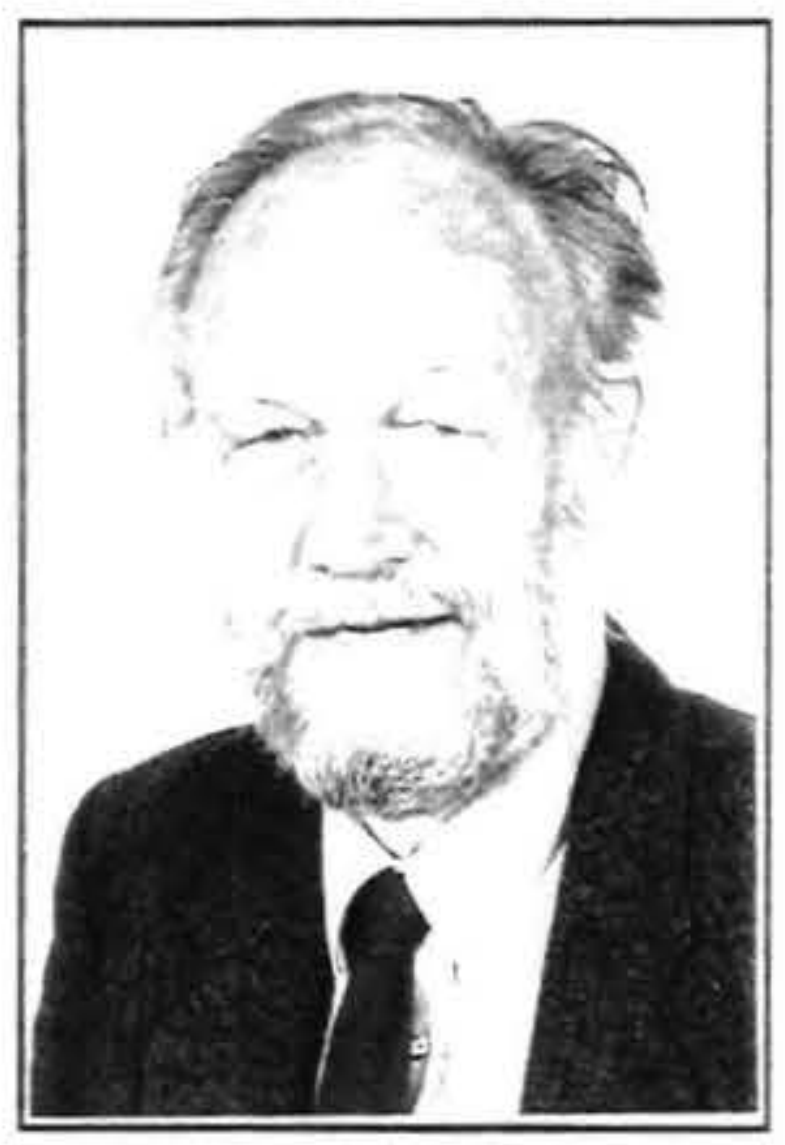

\begin{abstract}
The period of low economic growth from the mid 1980s to early 1990s has impacted particularly severely on Maori. In June 1994 the unemployment rate for Maori was 19.8 percent as opposed to 7.1 percent for non-Maori. Maori tend to be over-represented in manual occupations and in a number of industries particularly affected by economic restructuring. As part of a wider programme assessing Maori development, educational and training options Te Puni Kokiri commissioned Business and Economic Research Ltd (BERL) to produce a set of occupational and industry forecasts of employment in New Zealand for the year 2000. 1991 Census material was used to provide a detailed 25 occupation by 21 industry analysis of employment differentiated by sex and ethnicity, which was used as a base for projections. The forecasts to the year 2000 have been generated through the linked usage of a medium term three sector model of the economy, which produces macro economic trend forecasts, and a 21 sector version of the BERL general equilibrium model. The general equilibrium model has been extended to include 25 occupational categories and a vector of occupational substitution elasticities. The forecasts suggest that the predominant areas of employment growth will be in non-manual activities and in distribution and service industries.
\end{abstract}

The forecasts which we have recently completed for $\mathrm{Te}$ Puni Kokiri suggest that Maori and non-Maori employment will increase at similar overall rates in the period to the year 2000. Total employment is forecast to increase quite substantially, by some $16 \%$ in the period from 1993 to 2000 . The forecast rate of increase in Maori employment is slightly less at $15 \%$. Coming after the low growth of the late 1980 s and the early 1990 s these forecasts of a strong lift in employment are welcome but could be falsified in the event.

The forecasts suggest that a significant part (some $45 \%$ ) of the total increase in Maori employment will occur in the transformative industries (mining, manufacturing and building) and that there will be significant increases in Maori employment in trades, production and elementary occupational groupings. These are all areas in which employment suffered severely during the low growth or stagnation of the late 1980 s and early 1990 s and our forecasts of reasonably favourable trends in Maori employment are much influenced by our forecasts of growth in these industries.

It is noteworthy that whereas for the population as a whole some $64 \%$ of total employment opportunities will occur in distributive and service industries the corresponding figure for Maori is only 53\%. In an analogous way managerial and professional occupations are forecast to account for $35 \%$ for the whole population increase in employment as compared with only $20 \%$ for Maori.

\section{The Maori in employment}

Most forecasts of economic and social conditions foresee the continuation of trends which have tended to disadvantage Maori over recent decades. The transformation of New Zealand into an increasingly open and internationalised economy with rising skill levels is expected to reduce the relative importance of basic commodity production in both primary and manufacturing industries and increase the production of more sophisticated goods and services.

The ability of Maori to take advantage of these trends will depend to a considerable extent on success in developing appropriate educational and training strategies. The scale of the required adjustment can be illustrated with reference to some basic data on the current position of Maori within the paid workforce.

Maori are over-represented in industries (principally primary and manufacturing industries) that have been shedding labour and are not expected to offer large increases in employment over the medium term.

Figure 1 summarises the industrial patterns of Maori and non-Maori employment in mid-1994. The most striking feature is the dominance of service sector employment, which accounts for some $65 \%$ of total employment. Secondary industries (ie mining, manufacturing, electricity and construction) account for $25 \%$ and primary industries $10 \%$. 
Figure 1. Employment by industry

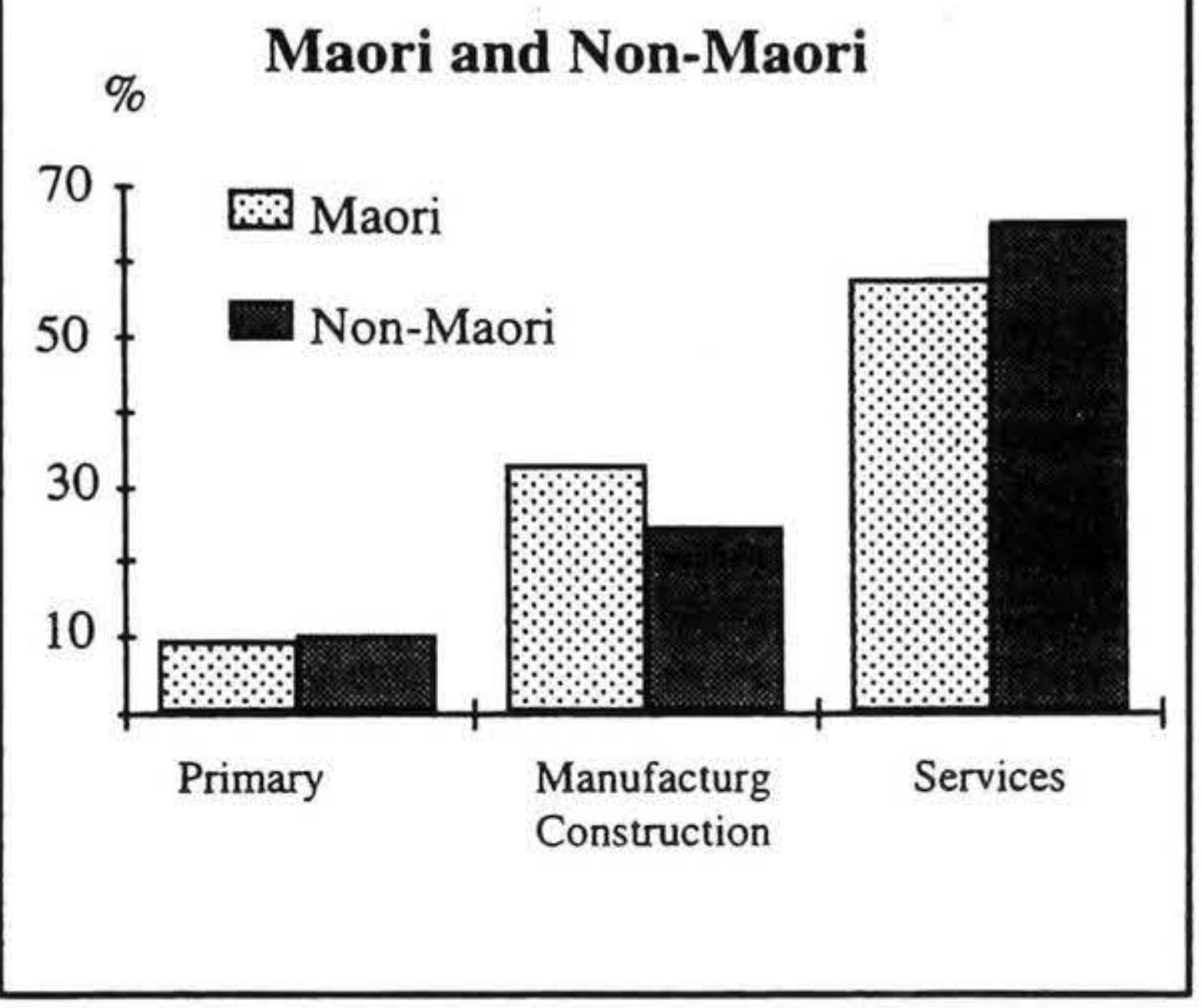

Maori employment is relatively concentrated in secondary industries (33\% for Maori as compared with $24 \%$ for nonMaori).

Although the majority of Maori, like the majority of nonMaori, are employed in service industries the proportion is noticeably less than for non-Maori (58\% for Maori as compared with $65 \%$ for non-Maori).

When viewed in occupational terms Maori are seen to be under-represented in higher skill occupations and over represented in those requiring lower skills. Figure 2 summarises the position as at mid-1994.

Figure 2 classifies people into one of four main categories; administrators, managers, professional and technical people, clerical and sales personnel, farmers and manual workers with skilled trades qualifications, and plant and machinery operators and elementary workers. The sharpest contrasts are evident at either end of this distribution.

Maori are significantly under-represented amongst ad-

Figure 2. Employment by occupation

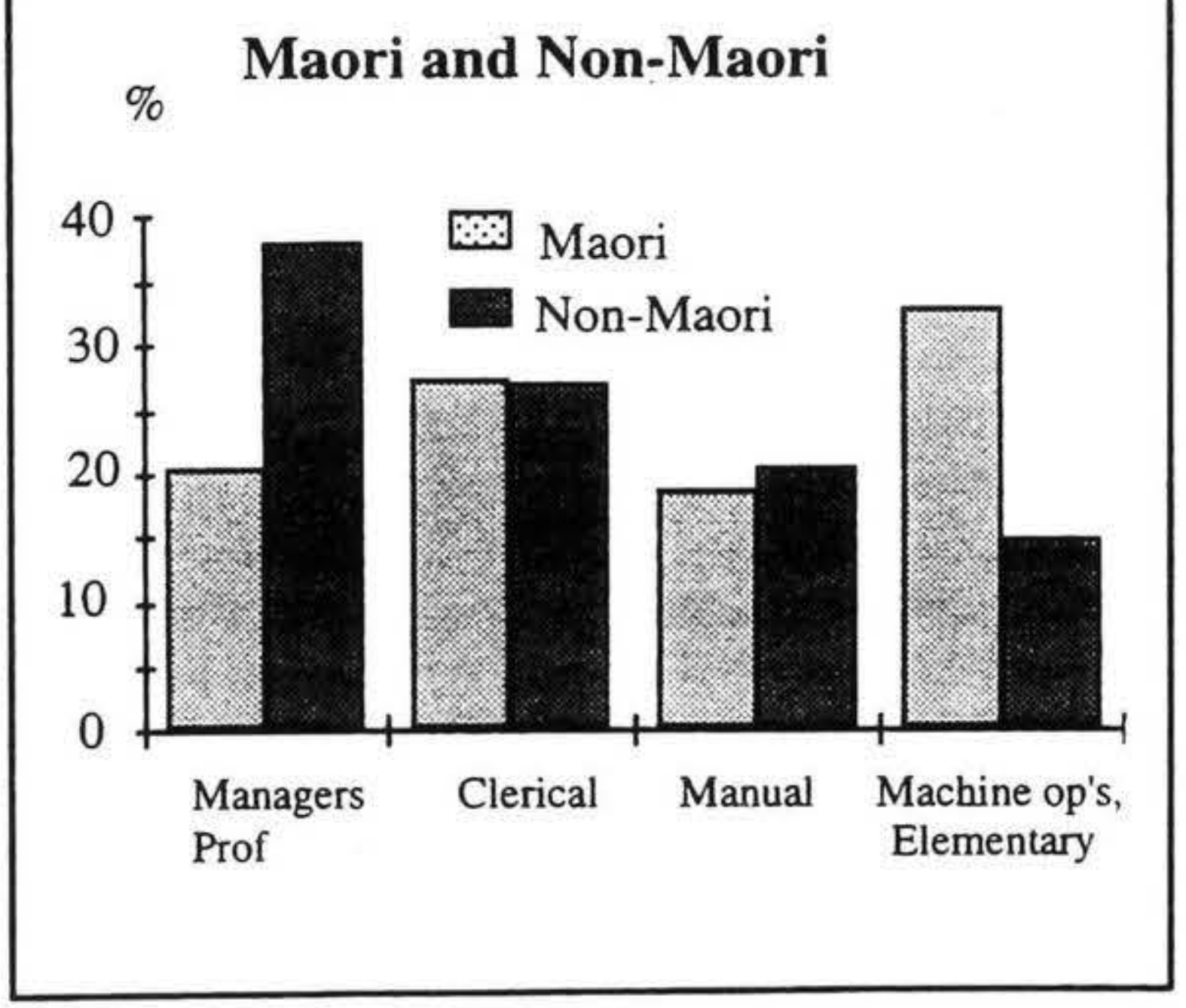

ministrative, managerial, professional and technical personnel. For Maori such employment accounts for only $20 \%$ of the total as compared with $38 \%$ for the non-Maori population. This under-representation is significant inasmuch as this group includes many of the dominant decision makers within the economy. The final group, which includes machine operatives and elementary workers such as labourers and cleaners has the largest concentration of Maori employment, $33 \%$ as compared with only $15 \%$ for the non-Maori population.

Many factors can contribute to ethnic differences in occupations including differences in opportunity, different aspirations and failures in public policy. These are controversial areas but whatever the cause of the noted differences it seems clear to us that they contribute to lower levels of income and greater exposure to the risk of unemployment.

The occupational story is reinforced by available information on educational qualifications. Figure 3 shows the position as at mid-1994 and effectively mirrors the picture shown in Figure 2. Our classification again distinguishes between four groups:

* persons with school and post school qualifications (typically graduates from polytechnics and universities);

* persons with school qualifications only (typically persons who can be expected to move into office type employment or become self employed);

* persons with no school qualifications but some form of post school qualification (typically tradespersons); and * persons with no qualifications (typically persons who will enter manual or elementary occupations).

As with the occupational data the sharpest contrasts are evident in the first and last categories. Some $22 \%$ of employed Maori have school and post school qualifications, as compared with $41 \%$ of non-Maori. In contrast some $42 \%$ of employed Maori have no qualifications at all as compared with only $22 \%$ of non-Maori.

High Maori unemployment rates are all too well recognised facts of life but they bear repeating. In June 1994 the Maori unemployment rate was $20 \%$ as compared with $7 \%$ for the non-Maori population. Unemployment is particularly severe in its impact on younger people. For the 15 to 24 age group the Maori unemployment rate is $31 \%$, for non-Maori $14 \%$.

The disadvantages which accrue from over representation in less skilled and lower paid occupations, over representation in slow growing industries and high rates of unemployment inevitably impact on the life chances of the children of the disadvantaged.

The scale of disadvantage is suggested by the following. In $26 \%$ of two parent Maori families, with children under five years old and where at least one of the parents is Maori, neither parent is in paid work. For two parent non-Maori 
Figure 3. Qualifications of employed and unemployed persons, Maori and non-Maori
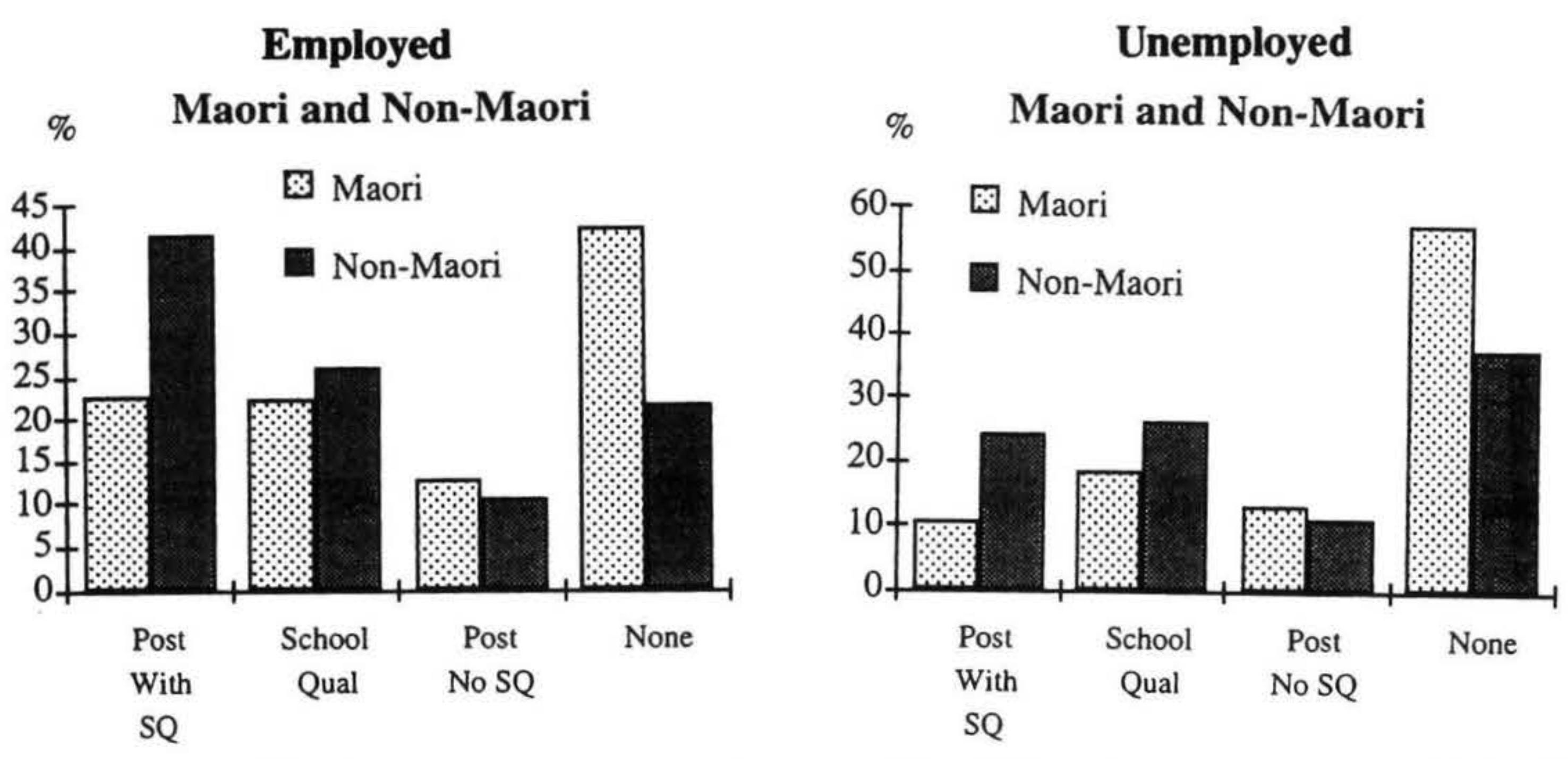

families the comparable figure is only $10 \%$. Some $40 \%$ of Maori children under age 5 are living in sole parent families, whereas the comparable figure for non-Maori families is $20 \%$ and $52 \%$ of Maori families with children under five have no market income.

\section{Some encouraging developments}

The trends reported above have generally been longstanding. A prolonged period of low growth coupled with the opening up of the economy to increased international competition and ongoing restructuring of state enterprises and institutions have impacted on everybody, but particularly on the lower skilled and particularly on populations whose members tend to have lower skills. Fortunately, these negative features do not present the whole picture.

As already noted the service sectors have long been the largest providers of employment. In the decade from 1981 to 1991 there were only five industries in which Maori employment increased both in absolute numbers and as a percentage of total employment. Each of these five industries was in the service sector. They are retail trade, banking and finance, business services, public administration and social and community services. These increases are encouraging.

Maori employment in middle and higher skilled occupations has been increasing more rapidly than non-Maori, in percentage terms, admittedly from fairly low levels. Maori female employment continued to expand in social and producer service industries right through the 1980s and, very much against the trend, this increase continued through the difficult years between 1986 and 1991 .

The index of occupational dissimilarity, for Maori women has fallen from $37 \%$ in 1971 , to $29 \%$ in 1981 , to $18 \%$ in 1991. The proportion for men has also been falling but at

a slower rate, from $30 \%$ in 1971 , to $24 \%$ in 1981 , to $22 \%$ in 1991.

This narrowing of occupational differences between Maori and non-Maori populations, is quite unlike the stickiness evident in similar indexes for differences between men and women in the population as a whole. Such gender differences are notably more pronounced and more persistent than differences between Maori and non-Maori.

It seems that Maori women have been able to adapt to changing economic circumstances somewhat more successfully than have Maori men. We note the faster closure of Maori female to non-Maori female patterns of employment, the faster growth of Maori female employment in service and professional activities and the somewhat lower rate of unemployment amongst Maori women.

There has been a significant increase in Maori participation in public service and educational sectors. It is probable that these increases are to some extent linked to the deliberate pursuit of equal opportunity policies.

\section{Occupational forecasts}

One of the primary purposes of the current project has been to develop a comprehensive set of employment forecasts, for the year 2000 , classified by industry and by occupation. The forecasts are approximate. We have endeavoured to make them as realistic as possible but the future is inherently uncertain. This uncertainty has till now discouraged the production of similar forecasts in New Zealand.

In contrast, in the United States the Bureau of Labor Statistics has been preparing comprehensive and very detailed industry and occupation forecasts regularly every two years for more than forty years. Those forecasts, and extensive occupational documentation built around them, are an integral part of the advisory services available to 
educators and policy makers in the United States. At an early stage in this project we benefited from discussions with the Bureau.

The forecasts presented here are much less ambitious, but are nevertheless a significant advance on information previously available in New Zealand. They have been developed within the context of an ongoing programme of economic modelling and forecasting whose primary focus has been on macro economic and industry level analysis, rather than occupational forecasting. Employment issues have however been a continuing concern of the programme and we have at various stages undertaken limited occupational analyses. ${ }^{1}$

The occupational forecasts presented later in this report have been generated through the linked usage of two economy wide models maintained and operated by BERL. ${ }^{2}$ The first, a three sector model, forecasts time paths for all major macro economic variables, including employment, investment, output, exports, imports, the balance of payments and the net international investment position, as shown in table 1 . We require our general equilibrium model of the economy to produce a detailed inter-industry picture which is consistent with macro economic outcomes for a selected future year, in this case the year 2000 . This picture includes detailed industry level information on output, employment, investment, exports and imports.

In the early years of the forecast, ie to the year 2000 , the three sector trend model generates a high rate of growth, with real GDP increasing at an average annual rate of $3.7 \%$. The main causes of this are:

* a reasonably strong, $4.4 \% \mathrm{pa}$, rate of growth in the volume of exports;

* continuing strong growth in labour productivity, $(2.0 \%$ pa), and a moderate rate of increase in capital productiv- ity, $(0.6 \% \mathrm{pa})$;

* a sustained period of new capital formation; and

* an economy in which three of the major macroeconomic variables (inflation, the external current account deficit and the balance in the government's own account) are close to balance and where the availability of unused labour resources, creates the possibility of, and indeed a need for, a faster expansion than could be sustained over the longer haul.

The export forecasts are based upon those published by NZIER in Quarterly Predictions. The productivity changes are based on projections prepared within BERL.

We note that this set of forecasts would be seen by many as fairly optimistic. Given our central interest in occupationally detailed forecasts of employment, perhaps the main point to acknowledge is that our forecasts envisage a return to full employment within the forecast horizon. Economic growth at rates less than forecast would delay such an outcome, which could also be put totally at risk by any of a number of possible developments including major international recession, public policy failures and strategic and adaptive shortcomings within the private sector. While such influences could have profound impacts on macro economic outcomes they seem unlikely to disturb the broad shape of the industrial pattern of activity generated within our forecasting systems.

Our modelling system provides two distinct pictures of developments in employment. The Three Sector model forecasts likely trends year by year over the forecast period. In addition the General Equilibrium model provides a detailed occupation by industry picture of employment for the year 2000. While the two models give us similar total level of employment in the year 2000 the industry detail is not so closely aligned. Although we use the Three Sector model to constrain total employment in

\section{Table 1: Macro-economic forecasts, three sector model}

\begin{tabular}{|c|c|c|c|}
\hline & $\begin{array}{l}\text { Model base } \\
1992\end{array}$ & $\begin{array}{l}\text { Projection } \\
2000\end{array}$ & $\begin{array}{l}\text { Rate of } \\
\% \text { pa }\end{array}$ \\
\hline Real GDP ( $\$$ billion) & 71.1 & 95.7 & 3.7 \\
\hline Real GDP per head (\$) & 20,810 & 25,610 & 2.6 \\
\hline Employment (000 FTE's) & 1,273 & 1,489 & 2.0 \\
\hline Unemployment rate (\%) & 9.5 & 4.8 & \\
\hline Investment to GDP ratio (\%) & 20.0 & 23.5 & \\
\hline Consumption to GDP ratio (\%) & 77.6 & 72.0 & \\
\hline Current account balance (\$m) & $-3,032$ & -729 & \\
\hline Imports to GDP ratio (\%) & 30.5 & 32.4 & \\
\hline $\begin{array}{l}\text { Net international investment position } \\
\text { (\% GDP) }\end{array}$ & -65.8 & -52.9 & \\
\hline
\end{tabular}

Source:BERL Three Sector Model run 24 October 1994/1.

Note:The net international investment position is a net measure of the stock of New Zealand direct and portfolio investment abroad, less the stock of foreign direct and portfolio investment in New Zealand. 
the General Equilibrium model, we do not force the latter to replicate the sector totals generated in the former. The more sophisticated routines of the General Equilibrium model present a more detailed picture of the economy and our normal practice is to let it sketch its picture of the economy with the minimum necessary number of constraints.

The three sector employment forecasts are displayed in figure 4. The main points stand out strongly: The first is the dominance of tertiary sector employment which accounts for $64 \%$ of total employment in 1993 as compared with $11 \%$ for primary sector employment and $25 \%$ for secondary employment.

Secondly, the tertiary sector also accounts for most of the forecast increase in employment, although the two models tell somewhat different stories about this. The Three Sector trend model suggests that the tertiary sector will provide 172,000 jobs out of an economy wide growth in employment of 200,000 in the period from 1993 to 2000 . The General Equilibrium model suggests that tertiary sector employment will increase by 130,000 out of a whole economy total of 197,000 over the same period.

The two models generate quite different rates of change in secondary sector employment, which increases by only 27,000 in the Three Sector model but rises by 70,000 in the General Equilibrium model.

The demand for occupations within an economy is driven by many forces. The demand for farmers, metal workers, shop assistants, bankers, teachers and nurses like those of all other occupations is driven by the patterns of personal and public demand for the products and services created by the persons in question and by the techniques by which such goods and services are produced at any point in time.
These influences are continually changing.

In summary, the main sets of influences working on the demand for occupations are the economy wide growth in total demand for output; changes in the industrial pattern of output; changes in occupational demand within particular industries, which in turn, are related to, changing levels of labour productivity in particular industries; changes in job content and specifications; the introduction of more or less capital intensive techniques and the substitution between different occupations.

These influences interact and in practice cannot be fully isolated from each other, but it will be useful to discuss them sequentially as a means of describing our modelling practice with respect to each of them.

As reported above, our forecasts suggest that employment will increase substantially in the period to 2000 , by some 200,000 full-time equivalents from the level prevailing in 1993. This substantial increase seems plausible when placed alongside the 89,000 increase in fulltime equivalent (FTE) employment in the two years to September 1994, but is in marked contrast to the experience of the past decade. From 1988 to 1993 employment fell by approximately 80,000 .

Changes in the industrial pattern of output obviously influence the pattern of demand for particular occupations. Faster growing industries call forth extra employment in occupations characteristically aligned with them. Thus the increasing relative importance of service industries is reflected in the increasing importance of office workers relative to trades and manual workers. The decline of the meat industry cuts back on demand for meat workers. Strong growth in tertiary education creates demand for lecturers.

Figure 4. Employment forecasts to 2000. Three sector and general equilibrium models compared

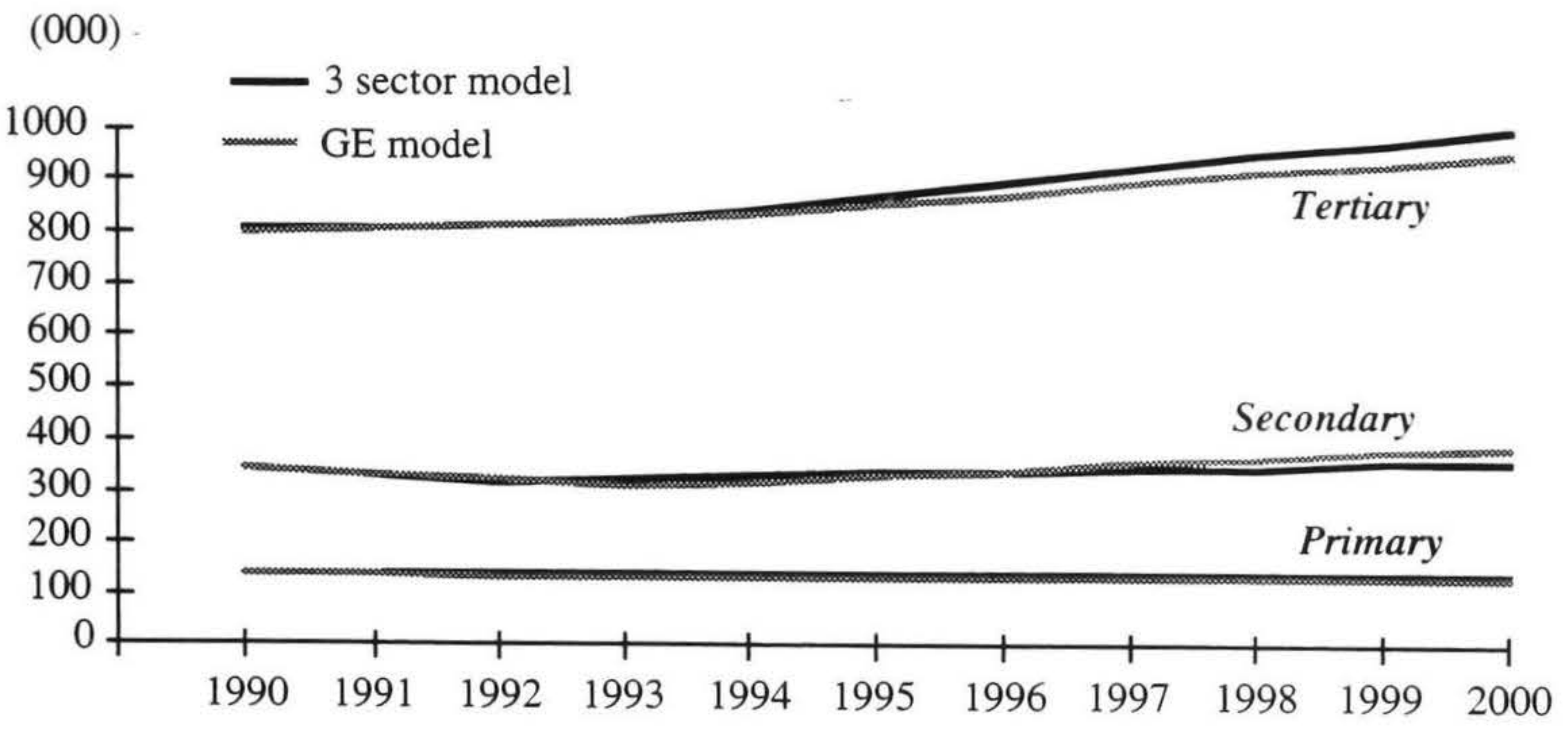


Within our models, demand for industry output is driven by a range of forces including changes in the pattern of consumer demand as income levels change and changes in world demand for New Zealand exports.

Table 2 summarises the industry level forecasts generated within the general equilibrium model. We have ranked industries according to forecast rates of growth in output.

As can be seen the industry growth rates show some marked differences with three industries recording growth rates of greater than $6 \% \mathrm{pa}$, seven between four and $6 \% \mathrm{pa}$, seven between two and $4 \% \mathrm{pa}$ and four recording rates less than $2 \%$.

Changes in demand for occupations within particular industries are driven by a range of forces. A major determinant of occupational demand within particular industries is related to ongoing changes in labour productivity. Over time, improvements in practice and techniques reduce the necessary amount of labour required to complete most tasks. Such rates of change in technique differ markedly between industries although many important changes such as, historically, the introduction of small electric engines and, more recently, the introduction of the personal computer, impact upon labour requirements in most industries. Most measures of labour productivity are industry focused but it is obvious that in practice the overall rate of labour productivity change in a particular industry will be a function of what will normally be different rates of change in labour productivity relating to the individual occupations engaged within an industry.

In our models we have followed general practice and introduced measures of expected changes in labour productivity which are specific to each industry but which are presumed to apply equally to all categories of labour employed within the industry. These forecast rates of change in labour productivity (along with rates of change in capital and total factor productivity) are based upon a continuing programme of industry level research undertaken at the NZ Planning Council, the Research Programme on Economic Planning at Victoria, and in the last few years at BERL with assistance from public good science funding from the Foundation for Research Science and Technology. The rates of change are summarised in table 2 above.

The demand for particular occupations is ultimately a demand for the particular services supplied by persons having particular sets of occupational skills. Such skill

Table 2: Industry Forecasts to 2000 (Annual Percentage Rates of Change)

\begin{tabular}{llll}
\hline & $\begin{array}{l}\text { Real Gross } \\
\text { Output }\end{array}$ & Employment & $\begin{array}{l}\text { Labour } \\
\text { Productivity }\end{array}$ \\
\hline Non-Metal Mineral Products & 8.6 & 5.7 & 2.8 \\
Construction & 7.0 & 5.6 & 1.4 \\
Mining \& Quarrying & 6.0 & 3.1 & 2.8 \\
Electricity, Gas \& Water & 5.7 & 2.6 & 3.0 \\
Forestry \& Logging & 5.6 & 2.4 & 2.1 \\
Fabricated Metal Prods: Other Manufacturing & 5.2 & 3.1 & 4.6 \\
Communications & 4.8 & 0.2 & 1.9 \\
Paper, Printing \& Publishing & 4.7 & 2.7 & 2.0 \\
Wood \& Wood Products & 4.5 & 2.5 & 0.6 \\
Fishing \& Hunting & 4.4 & 3.8 & 1.1 \\
Private Services & 3.5 & 2.4 & 3.0 \\
Transport & 3.3 & 0.3 & -0.9 \\
Wholesale \& Retail Trade, Restaurants \& Hotels & 3.3 & 4.3 & 3.7 \\
Food, Beverages \& Tobacco & 3.1 & 1.5 & 1.3 \\
Basic Metal Products & 2.9 & -0.8 & - \\
Chemicals, Plastics \&c & 2.7 & 1.3 & 1.4 \\
Ownership of Dwellings & 2.4 & -.3 & 0.1 \\
Textiles, Garments \& Footwear & 1.4 & 0.0 & 1.3 \\
Finance \& Business Services & 1.3 & 1.2 & 0.3 \\
Agriculture & 1.0 & -0.3 & 1.1 \\
Government Services & 1.0 & 0.8 & \\
TOTAL & 3.3 & 2.1 & \\
\hline
\end{tabular}

Source:BERL General Equilibrium model, Run 712

Note:Labour productivity is calculated with reference to forecast changes in real gross output and employment.

Unlike our input vector of labour productivity this measure is affected by capital/abour substitution. 
sets are constantly changing, both in response to changing techniques, which may reduce or eliminate the demand for some occupations whilst creating other new ones, and in response to shifting boundaries of responsibilities between occupational categories. Thus the development of computer software for many technical applications simultaneously cuts at the base of routine work that used to be performed by clerks using mechanical calculators and at the professional input of theoretically skilled people who used to specify calculating routines which can now be accomplished by standard packages. In all such cases employment impacts may be quite uncertain, as for example was evident in the early stages of electronic information technology in banking. Although the new technology displaced many functions, it also radically expanded the range of services available. Customers, in time, came to expect many of these new services to be available as a matter of course.

In building our occupational forecasts we have made no attempt to explicitly allow for such changes, some aspects of which will, however, at least be implicit in our industry level forecasts of changes in labour productivity.

Over time there is a persistent tendency to replace human labour by machines. At any point in time employers also face choices as to the degree of capital intensity adopted in production using currently available technologies. An expansion in production may be achievable through placing more people on an existing production line or it may be possible to expand the capacity of the line by adding an extra machine. Theory suggests that the balance struck between use of labour and capital in such situations can be seen as being determined within a production function in which output is algebraically related to inputs of labour and capital.

Our models incorporate extensive routines for modelling changes in the balance between labour and capital usage. The more important driving forces are the exogenously specified rates of change in labour and capital productivity which are based on our ongoing programme of industry research in this area and the pattern of relative price shifts which develops within the model but which is conditioned by exogenous assumptions on shifts in the New Zealand and world price levels and in New Zealand's terms of trade.
At any point in time and for any set of particular occupational skills and abilities the relative demand for particular occupations can be expected to be price sensitive. In the same way as employers can be expected to substitute between labour and capital, so they can be expected to contemplate substitution between different categories of labour when this would contribute to lower total costs for any particular level of output.

The general equilibrium model includes production functions which enable each occupation to be specified as a separate input to each industry so allowing the model to substitute between occupations when this will contribute to lower total costs. This expanded production function requires information specifying the elasticities of substitution relating to each pair of occupations specified in the model. Such elasticities were estimated using 1986 and 1991 Census data on employment and incomes classified on a 25 occupation by 21 industry basis on the assumption that the technical ease of substituting between each pair of occupations is the same in all industries.

The projections of occupational employment are shown in figure 5 which displays the 25 occupation by 21 industry matrix of numbers employed on an FTE basis in the year 2000. The same information is presented in more summary form in tables 3 and 4 .

The tables show for four industry and eight occupational groups the estimated numbers employed in 1993 and projected in 2000; the absolute and percentage growth over the period; and the contribution made by its growth to total employment growth (of over 200,000 FTEs).

The contribution to employment growth reflects the relative size of industries and the growth projections discussed in the previous section. Primary industries show a net loss of employment, with losses in Agriculture outweighing growth in Fishing and Forestry.

Almost half of the employment growth in Transformative industries is from Construction, then eventually spread through other industries in the group. Employment growth in the Distributive industries is totally dominated by Trade.

Within Services industries, only Private Services are projected to have an above-average growth rate - the others are significantly below average.

Table 3: Employment by Industry, 1993 and 2000

\begin{tabular}{|c|c|c|c|c|c|}
\hline \multirow{2}{*}{$\begin{array}{l}\text { Industry } \\
\text { Group }\end{array}$} & \multicolumn{2}{|c|}{$\begin{array}{c}\text { Numbers Employed } \\
{[000 \text { s FTEs] }}\end{array}$} & \multicolumn{2}{|c|}{$\begin{array}{c}\text { Change } \\
1993-2000\end{array}$} & \multirow{2}{*}{$\begin{array}{r}\text { Contribution } \\
\text { to change } \\
\%\end{array}$} \\
\hline & 1993 & 2000 & $000 \mathrm{~s}$ & $\%$ & \\
\hline Primary & 131.7 & 131.4 & -0.4 & -0.3 & -0.2 \\
\hline Transformative & 315.0 & 386.6 & 71.6 & 22.7 & 35.6 \\
\hline Distributive & 336.2 & 424.6 & 88.4 & 26.3 & 44.0 \\
\hline Services & 483.3 & 524.5 & 41.3 & 8.5 & 20.5 \\
\hline Total & $1,266.1$ & $1,467.0$ & 200.9 & 15.9 & 100.0 \\
\hline
\end{tabular}




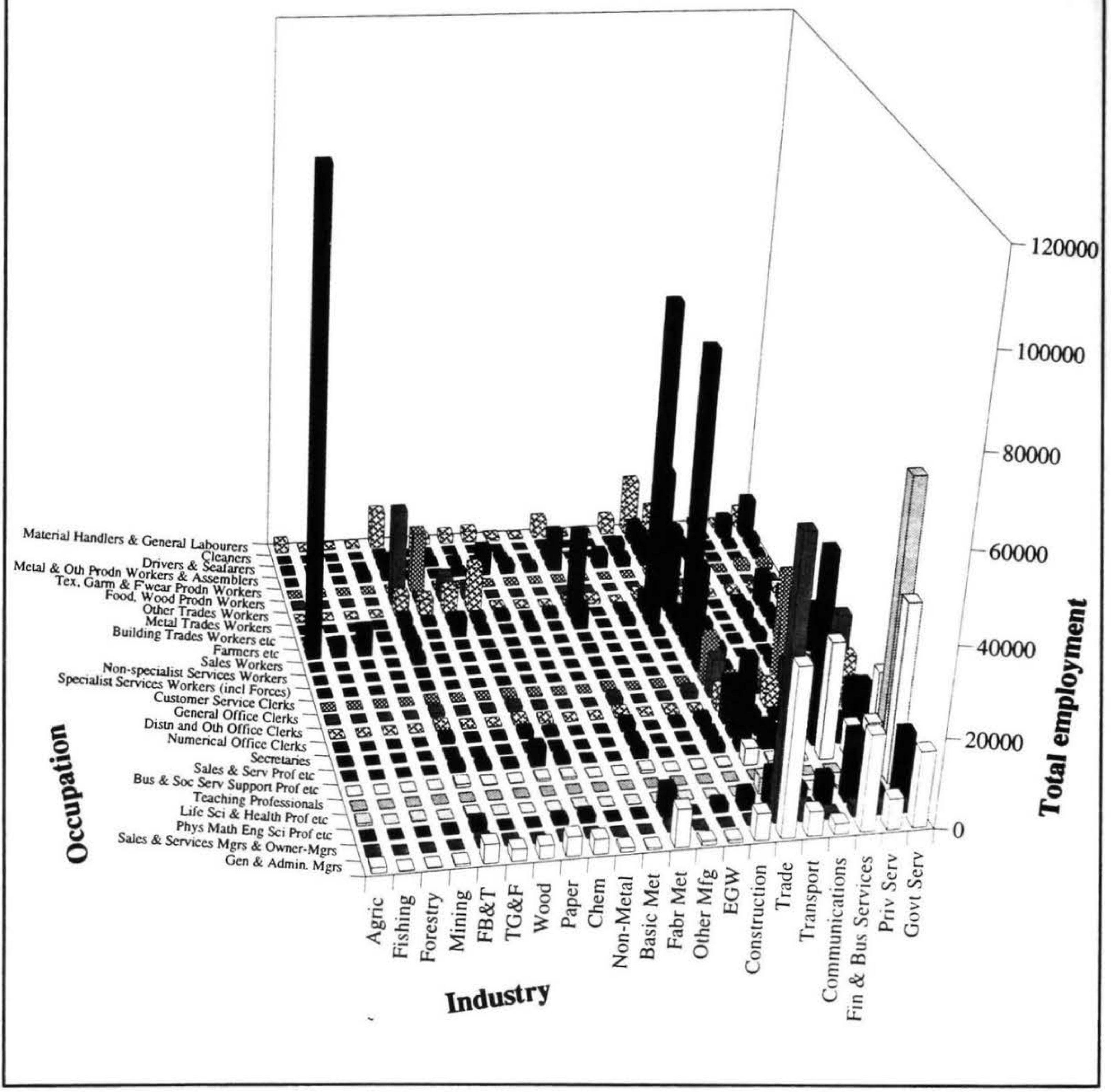

Table 4: Employment by occupation, 1993 and 2000

\begin{tabular}{lllllc}
\hline & \multicolumn{2}{c}{$\begin{array}{c}\text { Numbers Employed } \\
\text { [000s FTEs] }\end{array}$} & \multicolumn{2}{c}{$\begin{array}{c}\text { Change } \\
\text { 1993-2000 }\end{array}$} & $\begin{array}{c}\text { Contribution } \\
\text { to change } \\
\text { Occupational }\end{array}$ \\
Group & 1993 & 2000 & 000 s & $\%$ & 18.3 \\
\hline Managers & 167.9 & 204.4 & 36.7 & 21.9 & 16.8 \\
Prof nals \& Assoc Prof & 299.0 & 332.8 & 33.8 & 11.3 & 11.9 \\
Clerical & 177.5 & 201.3 & 23.9 & 13.5 & 16.1 \\
Sales \& Services & 143.1 & 175.4 & 32.3 & 22.6 & 0.7 \\
Primary & 131.8 & 133.2 & 1.4 & 1.1 & 23.4 \\
Trades & 164.0 & 211.0 & 47.0 & 28.6 & 7.5 \\
Production & 117.3 & 132.4 & 14.1 & 16.4 & 5.4 \\
Elementary & 65.7 & 76.5 & 10.8 & 15.9 & 100.0 \\
Total & $1,266.1$ & $1,467.0$ & 200.9 & 15.9 & \\
\hline
\end{tabular}


Growth projections for occupational groups are shown in table 4. The main influence on occupation growth is industry composition and change, ie growth for any occupational depends on relative employment within high-, medium- and low-growth industries. In this particular set of projections the inter-occupational substitution elasticities do not play a part because we have made no assumptions about the supply of labour.

Conclusions about the future composition of employment growth within occupations are that:

* Managerial occupations will make a significant contribution to employment growth.

* The growth in Professional \& Associate Professional employment is expected to be below average, as a result of their concentration in Finance \& Business Services and Government Services; but they make a significant contribution to employment growth largely as a result of their relative size.

* A similar trend is observed amongst Clerical employment.

* Sales \& Services occupations show above average employment growth.

* Low output growth leads to negligible employment growth in industry-specific Primary occupations.

* Trades occupations exhibit the highest growth rate and contribution to employment growth of any occupational group, and over half of this is in Building Trades \& Other Construction Workers reflecting high levels of investment.

* Production and Elementary occupations make a relatively small contribution to overall employment growth

\section{Occupational projections for Maori}

Separate projections for Maori industry by occupation employment for the year 2000 are based on Maori retaining the same percentage share of each occupation-byindustry cell in 1993 and 2000 as they did in 1991 . The results suggest that the overall rates of change in Maori and non-Maori employment will be similar. Total Maori employment growth is slightly lower, $15.2 \%$ versus $15.9 \%$ for the total population, a difference of only a tenth of a percentage point a year. This is somewhat surprising Maori are projected to experience slightly lower employment growth in virtually all industries and occupations except Primary (a reflection of under-representation in declining Agriculture and over-representation in highgrowth Fishing and Forestry - but the latter are still a relatively small share of total Maori employment). Maori employment tends to be in lower growth industry/occupational combinations, but the aggregate effect does not make a major difference to the final outcome.

A number of significant differences emerge, in that Maori employment growth is much more concentrated than average in Transformative industries, and less so in Distributive industries. Maori employment benefits to an average extent from growth in Trades and Sales \& Services occupations, but is much more concentrated than average in other manual occupations (Primary, Product and Elementary) and less than average in other non-manual occupations (Managerial, Professional, Clerical).

The picture is one where the makeup of Maori employment growth varies quite significantly from the overall pattern, largely as a result of its initial occupational and industry distribution; but the net effect is that total growth is only slightly below average.

\section{Conclusion}

In conclusion two important qualifications to the above analysis should be noted. First, Maori employment growth at about the same rate as the rest of the population is a positive trend, especially when viewed against the experience of the recent past, but it needs to be placed in context, alongside the significantly higher current rate of Maori unemployment and the lower rate of Maori labour force participation. In addition the Maori population and labour force are increasing more rapidly than those of New Zealand as a whole. Secondly we are conscious of the extent to which the fast growth in Maori employment suggested by our forecasts is conditioned by the high levels of building activity resulting from fast rates of growth in GDP. A faltering in that growth could easily transform the picture once again.

\section{Future research}

In developing the forecasts and projections presented in this paper we have been forced to give some matters less attention than they deserve. Four of these are discussed briefly below.

To this point our occupational projections have not involved direct empirical work on changing trends in occupational demand within particular industries analogous to the work undertaken by the US Bureau of Labor Statistics. This seems likely to be a rewarding area for further work.

Secondly there is a need to explore the sensitivity of the projections to various possible changes in forecasting assumptions. For example, we have established that the demand for tradespeople is strongly influenced by the rate of capital formation, which in turn reacts to the rate of growth established in any particular model run. Similarly, the demand for teaching and health professionals is strongly influenced by the assumptions that we have made about the likely rate of change in government consumption spending. There is a need to explore just how sensitive the occupational composition of employment is to such changes.

The occupational projections focus on trends in labour demand. It would be useful to relate these to what is known about likely future trends in labour supply. It would be 
possible to generate a number of whole population projections embodying different assumptions relating tochanges in the supply of skills and associated changes in unemployment rates. Such assumptions would enable us to engage the inter-occupational substitution elasticities which have not been significantly activated in the projections prepared to this point.

Finally, it would also be possible to develop a complementary quantitative modelling approach exploring the extent to which it is possible, over a period of time, to change the occupational and skill profiles of the population.

\section{References}

Philpott, Bryan 1990 Labour market flexibility in a general equilibrium analysis of paths to full employment. Occasional Paper 98, Research project on economic planning, Victoria University of Wellington, Wellington.

Philpott, Bryan and Stroombergen, Adolf 1986 Analysing flexible labour markets - a general equilibrium approach using CRESH production functions. Occasional Paper 87, Research project on economic planning, Victoria University of Wellington, Wellington.

Rose, Dennis 1990 The fully employed high income society, New Zealand Planning Council.

\section{Notes}

${ }^{1}$ See for example: discussion in pp20-22 of Rose, Dennis The Fully Employed High Income Society NZ Planning Council, 1990; Philpott, Bryan. Labour Market Flexibility in a General Equilibrium Analysis of Paths to Full Employment. Occasional Paper 98, Research Project on Economic Planning, Victoria University of Wellington, 1990; and Philpott, Bryan and Adolf Stroombergen Analysing Flexible Labour Markets - A General Equilibrium Approach Using CRESH Production Functions Occasional Paper 87, Research Project on Economic Planning, Victoria University of Wellington, 1986.

2 The modelling programme also embodies insights developed over a long period through work undertaken at BERL, at the Research Programme on Economic Planning at Victoria University and, throughout the 1980 s, at the NZ Planning Council. More recently the programme has been supported through a number of contracts awarded by the Foundation for Research Science and Technology and public sector clients.

\section{Authors}

Grant Andrews and Dennis Rose are both economists at BERL (Business and Economics Research Ltd), Weddel House, 158 The Terrace, Wellington. 